\title{
Co-composting of Petroleum Sludge with Poultry Manure
}

\author{
Lavania Baloo, Ruvindran Vasu, Nuraziany Binti Mohd Azmi, Noor Amila Wan Abdullah \\ Zawawi
}

\begin{abstract}
Petroleum sludge (PS) is a well-known hazardous waste because of its complicated compound. Leaching of petroleum sludge becomes a major threat to the environment if the waste is dumped illegally in landfills without proper treatment. Since, the petroleum sludge has the tendency to infiltrate into ground, eventually contaminates the soil and ground water. Therefore, the petroleum sludge needs to be treated before disposal to eliminate the negative impact to the environment. In this study, composting of PS by adding sawdust, soil and poultry manure has been carried out to produce compost that is low in polycyclic aromatic hydrocarbons (PAHs), heavy metals and with higher nutrient content. Each of the compost combination was homogenously mixed and stored in plastic container with good aeration using various ratios of 1:1:1:0 (control), 1:1:1:5, 1:1:1:8 and 1:1:1:10 volume-volume basis respectively, for two weeks. The result for PAHs by using Gas Chromatography/ Mass Spectrophotometry (GC/MS) shows fourteen types of PAH detected in PS. The total reduction of PAH in composts mixed were found to be $0.97 \%, 2.44 \%, 3,43 \%$ and $2.53 \%$ in compost design mix of 1:1:1:0, 1:1:1:5, 1:1:1:8 and 1:1:1:10, respectively. Besides, the result for heavy metals such as $\mathrm{Al}, \mathrm{Fe}, \mathrm{Cu}, \mathrm{Zn}, \mathrm{Pb}$ and Cd by using Atomic Absorption Spectrometer (AAS) shows the concentration in $\mathrm{Fe}$ (450.65) > Al (338.07) > $\mathrm{Zn} \mathrm{(52.7)} \mathrm{>} \mathrm{Pb}$ (40.73) > Cd (39.56) > Cu (19.56) ppm. The best heavy metals reduction occurs to be in ratio of 1:1:1:10 where the $\mathrm{Al}, \mathrm{Fe}, \mathrm{Cu}$, $\mathrm{Zn}, \mathrm{Pb}$ and $\mathrm{Cd}$ decreased by 3.05\%, 2.67\%, 3.37\%, 0.11\%, $9.16 \%$ and $6.45 \%$ respectively. The carbon and nitrogen content in each ratio were determined by Total Organic Carbon (TOC) analysis and Total Kjedahl Nitrogen (TKN) analysis during the composting period. The Carbon to Nitrogen (C:N) ratio was maintained between 25 to 30 throughout the composting period. The composting process created a favorable condition for the microbial degradation of PS. Hence, based on the results obtained, best performing ratio to treat PS has been confirmed with ratio of 1:1:1:8. As a conclusion, co-composting can be a promising treatment method for disposal of PS.
\end{abstract}

Revised Manuscript Received on December 05, 2019.

* Correspondence Author

Lavania Baloo*, Civil \& Environmental Engineering Department, Universiti Teknologi PETRONAS, Seri Iskandar, Malaysia. Email: lavania.baloo@utp.edu.my

Ruvindran Vasu, Civil \& Environmental Engineering Department, Universiti Teknologi PETRONAS, Seri Iskandar, Malaysia. Email: ruvindran_19001047@utp.edu.my

Nuraziany Binti Mohd Azmi, Civil \& Environmental Engineering Department, Universiti Teknologi PETRONAS, Seri Iskandar, Malaysia. Email: nuraziany.mohdazmi@gmail.com

Noor Amila Wan Abdullah Zawawi, Civil \& Environmental Engineering Department, Universiti Teknologi PETRONAS, Seri Iskandar, Malaysia. Email: amilawa@utp.edu.my
Keywords : bulking agents, characterization, co-composting, heavy metals, petroleum sludge, polycyclic aromatic hydrocarbon, poultry manure, sawdust, treatment.

\section{INTRODUCTION}

$\mathrm{P}$ etroleum sludge is one of the most important solid waste generated from the oil and gas industry from the exploration, production, transportation, storage, and refinery process [1]. The composition of PS is different hinge on the inception and storage state. PS is generally classified as a complex and stable emulsion-suspension system, with polycyclic aromatic hydrocarbons (PAH) and heavy metals [2]. Aliphatic and aromatics are the two major fractions of the sludge as it accounts up to $75 \%$ of the total content. The common compound that are found in these fractions are alkanes, cycloalkanes, benzene, toluene, xylenes, naphthalene, phenols, and various polycyclic aromatic hydrocarbons (PAHs)[3]. From a report of Petroleum Development Oman (PDO), which is the leading oil and gas exploration and production company produces almost 1800 tonnes of oily tank bottom sludge, 53000 tonnes of petroleum contaminated soil and 1000 tonnes of mud cutting per year, and $30 \%$ of the world's oil and gas is produced in offshore production accounts and is expected to increase further in future [4].

The uncontrolled production of PS has been a global concern recently. PS generated by petroleum industry leads to the environmental pollution and human risks. The sludge has the capability to pass through the ground and contaminated the soil, water and air. Human health effects from the exposure of PS such as headache, nausea and dizziness are caused from the breathing of the petroleum vapors which effected the nervous system, and respiratory irritation. PS also can cause failure to the human's blood and kidneys Moreover, the humans could face coma and death if the exposure is very high. In Malaysia, $48 \%$ rivers around the country is found to be polluted by the impact of industrial waste disposal. PS is a hazardous waste and need to be treated before disposing [3]. There are several treatments available, such as land-farming, incineration, thermal treatment, stabilization/solidification, solvent extraction, ultrasonic treatment, pyrolysis, photocatalyst, chemical treatment, and composting [5].

In recent years, the sludge produced during the refinery process of crude oil have received significant attention from the industry and environmentalist. Therefore, many studies in the past have carried out different kind of treatments to treat the PS. PS need to be 
treated before disposing because of its hazardous waste. Besides that, the treatment of PS is also to reduce the volume of wastes disposed to conserve the landfills.

Composting is one of the treatments used to treat the PS. The process requires the presence of bacteria to decompose the wastes. The composting method can be operated by using different kind of materials such as organic solid waste (green waste), animal manure, bedding, human excrete, and sewage sludge. Composting consists of various methods such as in-vessel composting, aerated static pile composting, vermicomposting, and windrow composting. Therefore, the aim of this study was to perform composting of the PS with the addition of bulking agent and poultry manure to treat and degrades the toxic substances in PS. Thus, for effective composting process the characteristics of petroleum sludge such as polycyclic aromatic hydrocarbons (PAHs) and heavy metals content were identified. Furthermore, the suitable and optimum sludge to bulking agent to poultry manure ratio of the compost was also determined. As a result, this study was able to produce a composted product which has low amount of PAH content and with high nutrient content.

\section{A. Polycyclic Aromatic Hydrocarbon Content of Petroleum Sludge}

PS is a complex chemical composition containing a mixture of sediments, water, oil, and high hydrocarbon concentration $[6,7]$. It has high content of cycloalkanes, and aromatic compounds primarily in alkanes, and paraffins of 1-40 carbon atoms [6-8]. The high content of polyaromatic hydrocarbon $(\mathrm{PAH}) \quad[6,7]$ created from the petroleum-refining, treatment of waste, and oil storage vessels clearing [7] resulting in the production of hazardous waste product [8]. The production of dangerous waste product generated by the petroleum industries in significant amount of sludge leads to the environmental pollution [5]. The sludge has the capability to pass through the ground and contaminate the soil, water and air [2]. Based on the studies, some of the polycyclic aromatic hydrocarbons (PAHs) which present in PS are shown in Fig 1 and detailed description of the hydrocarbons are illustrated in Table 1 [6].<smiles>c1ccc2ccccc2c1</smiles>

Naphthalene

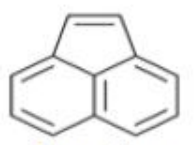

Phenanthrene
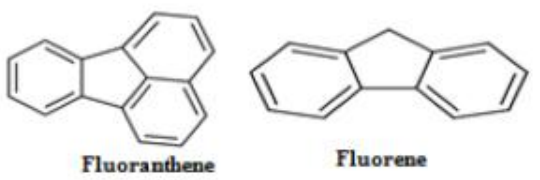
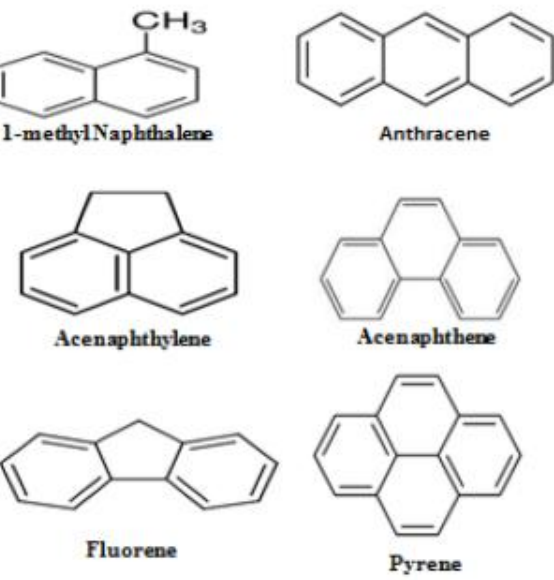

Fig. 1.Polycyclic aromatic hydrocarbon (PAH) of environmental concern present in oil-sludge [6].

Table- I: Summary of Common Form of PAH

\begin{tabular}{|c|c|c|c|}
\hline $\begin{array}{c}\text { No } \\
\text {. }\end{array}$ & $\begin{array}{c}\text { Hydrocarbo } \\
\text { n }\end{array}$ & Descriptions & Ref \\
\hline 1 & Naphthalene & $\begin{array}{l}\text { Naphthalene has a molecular formula } \\
\mathrm{C} 10 \mathrm{H} 8 \text { and structure of two fused } \\
\text { benzene rings. }\end{array}$ & {$[6,9]$} \\
\hline 2 & Fluoranthene & $\begin{array}{l}\text { Fluoranthene, a no alternant PAH } \\
\text { containing a five-membered ring, has } \\
\text { been shown to be metabolized by a } \\
\text { variety of bacteria, and pathways } \\
\text { describing its biodegradation have } \\
\text { been proposed. } \\
\text { Fluoranthene has been used as a } \\
\text { model compound in studies which } \\
\text { have investigated the effects of } \\
\text { surface-active compounds on PAH } \\
\text { biodegradation }\end{array}$ & {$[10]$} \\
\hline 3 & Fluorene & $\begin{array}{l}\text { Fluorene is a polycyclic aromatic } \\
\text { hydrocarbon and has been found to be } \\
\text { susceptible to microbial degradation } \\
\text { to varying extent. }\end{array}$ & [6] \\
\hline 4 & Pyrene & $\begin{array}{l}\text { Pyrene is a PAH consisting of four } \\
\text { fused benzene rings. It is the smallest } \\
\text { peri-fused PAH (the rings are fused } \\
\text { through more than one face). } \\
\text { Many microorganisms have shown } \\
\text { the capability of utilizing four ringed } \\
\text { aromatic hydrocarbons. }\end{array}$ & [11] \\
\hline 5 & Anthracene & $\begin{array}{l}\text { This is a polycyclic aromatic } \\
\text { hydrocarbon consisting of three fused } \\
\text { benzene rings. } \\
\text { The initial reactions in the bacterial } \\
\text { degradation of anthracene involve the } \\
\text { formation of trans-1, } \\
\text { 2-dihydroxyanthracene prior to ring } \\
\text { fission [23]. }\end{array}$ & [12] \\
\hline 6 & Phenanthrene & $\begin{array}{l}\text { Phenanthrene is a polycyclic aromatic } \\
\text { hydrocarbon composed of three fused } \\
\text { benzene rings. Many species of } \\
\text { bacteria found }\end{array}$ & {$[12]$} \\
\hline
\end{tabular}

PS must be treated properly as it has high chance to risk the health of citizen nearby [1]. Disposing the waste or directly put the waste on fire without go through any treatment will cause a serious environmental consequence and increase the hazard in health to both ecosystems and human health $[6,8]$. However, as today is in the era of development, to find the suitable landfill sites to dump the treated petroleum waste are becoming very limited [13]. Studies have shown various of treatments (e.g. solvent extraction) to treat the PS in objectives to decrease the amount of waste, to conserve landfill space, and to reduce the environmental pollution. Meanwhile, some studies used composting to treat the sludge.

\section{B. Heavy Metals Content in Petroleum Sludge}

Heavy metals present in the petroleum sludge impose a huge impact on the human impact and environment. Based previous studies, the elements present in the petroleum sludge are zinc, copper, chromium, lead, cadmium, nickel and etc [14]. Table II shows the effect of heavy metals on human health.

Table- II: Effects of Heavy Metals found in Petroleum Sludge on Human Health

\begin{tabular}{|c|c|c|}
\hline Elements & Effect on human health & Ref \\
\hline Arsenic & Bronchitis, dermatitis, poisoning & \\
\hline Cadmium & $\begin{array}{l}\text { Renal dysfunction, lung disease, lung cancer, } \\
\text { bone defects, increase blood, and }{ }^{2} \text {, ssure, gkidney } \\
\text { damage, bronchitis }\end{array}$ & [15] \\
\hline
\end{tabular}




\begin{tabular}{|l|l|}
\hline Lead & $\begin{array}{l}\text { Mental retardation in children, development } \\
\text { delay, fatal infant, chronic damage to the } \\
\text { nervous system. }\end{array}$ \\
\hline Manganese & $\begin{array}{l}\text { Inhalation or contact causes damage to central } \\
\text { nervous system. }\end{array}$ \\
\hline Mercury & $\begin{array}{l}\text { Tremors, gingivitis, minor psychological } \\
\text { changes, acrodynia characterized by pink hands } \\
\text { and feet, spontaneous absorption, damage to } \\
\text { nervous system. }\end{array}$ \\
\hline Zinc & $\begin{array}{l}\text { Zinc fumes have corrosive effect on skin causes } \\
\text { damage to nervous membrane. }\end{array}$ \\
\hline Chromium & $\begin{array}{l}\text { Damage to the nervous system, fatigue, } \\
\text { irritability. }\end{array}$ \\
\hline Copper & $\begin{array}{l}\text { Anemia, liver and kidney damage, stomach and } \\
\text { intestinal irritation. }\end{array}$ \\
\hline
\end{tabular}

Table III shows the elements and its concentration present in PS by previous studies. Based on the Table III, Zinc was in highest concentration in PS whereas, Beryllium was in the lowest concentration in PS.

Table- III: Heavy Metals present in Petroleum Sludge

\begin{tabular}{|l|l||l|l|}
\hline \multicolumn{1}{|c|}{ Element } & $\begin{array}{c}\text { Concentration } \\
(\mathbf{m g} / \mathbf{k g})\end{array}$ & \multicolumn{1}{|c|}{ Element } & $\begin{array}{c}\text { Concentration } \\
(\mathbf{m g} / \mathbf{k g})\end{array}$ \\
\hline $\mathrm{Cu}$ & 4420.46 & $\mathrm{Li}$ & 47.92 \\
\hline $\mathrm{Fe}$ & 4033.58 & $\mathrm{Sr}$ & 43.33 \\
\hline $\mathrm{Mo}$ & 2269.54 & $\mathrm{~V}$ & 8.28 \\
\hline $\mathrm{B}$ & 1369.36 & $\mathrm{Ag}$ & 6.18 \\
\hline $\mathrm{Zn}$ & 12248.7 & $\mathrm{As}$ & 4.96 \\
\hline $\mathrm{Mn}$ & 398.06 & $\mathrm{Cd}$ & 4.44 \\
\hline $\mathrm{Al}$ & 273.02 & $\mathrm{Co}$ & 3.78 \\
\hline $\mathrm{Pb}$ & 132.7 & $\mathrm{Hg}$ & 3.49 \\
\hline $\mathrm{Cr}$ & 119.09 & $\mathrm{Sb}$ & 2.88 \\
\hline $\mathrm{Ba}$ & 110.33 & $\mathrm{Se}$ & 0.14 \\
\hline $\mathrm{Sn}$ & 58.65 & $\mathrm{Tl}$ & 0.13 \\
\hline $\mathrm{Ni}$ & 56.01 & $\mathrm{Be}$ & 0.01 \\
\hline
\end{tabular}

\section{Available Treatment Methods for Petroleum Sludge}

Petroleum sludge can be treated by adopting many methods. Based on past studies, there are nine potential methods to treat the petroleum sludge. Table IV shows the available methods used to treat petroleum sludge.

Table- IV: Available methods to treat Petroleum Sludge

\begin{tabular}{|c|l|l|l|}
\hline $\begin{array}{c}\text { No } \\
.\end{array}$ & \multicolumn{1}{|c|}{ Method } & \multicolumn{1}{|c|}{ Description } & Ref \\
\hline 1. & $\begin{array}{l}\text { Solvent } \\
\text { Extraction }\end{array}$ & $\begin{array}{l}\text { Large amount of organic } \\
\text { solvents is used }\end{array}$ & {$[3,17]$} \\
& & $\begin{array}{l}\text { Unable to extract water, solid } \\
\text { particles, carbonaceous } \\
\text { impurities and heavy metals. } \\
\text { The effectiveness of the method } \\
\text { is affected by temperature and } \\
\text { pressure solvent-to-sludge } \\
\text { ratio, mixing, and solvent itself. }\end{array}$ & \\
\hline 2. & Centrifugation & $\begin{array}{l}\text { Components are divided } \\
\text { according to their densities. }\end{array}$ & {$[3,18]$} \\
& & $\begin{array}{l}\text { Uses a special high-speed } \\
\text { rotation equipment. } \\
\text { Adding organic solvents could } \\
\text { reduce viscosity of petroleum } \\
\text { sludge. }\end{array}$ & \\
\hline
\end{tabular}

\begin{tabular}{|c|c|c|c|}
\hline & & $\begin{array}{l}\text { - Demulsifying agent or chemical } \\
\text { conditioners used to mix with } \\
\text { petroleum sludges. } \\
\text { - To minimize the viscosity, the } \\
\text { mixture will be treated by hot } \\
\text { steam. } \\
\text { - After centrifugation, the water } \\
\text { will be drained for further } \\
\text { treatment due to high } \\
\text { concentration of PHCs. - }\end{array}$ & \\
\hline 3. & $\begin{array}{l}\text { Surfactant } \\
\text { EOR }\end{array}$ & $\begin{array}{l}\text { - Removes organic pollutants } \\
\text { from solid matrices. } \\
\text { - Surfactant is amphiphilic } \\
\text { compound with hydrophobic } \\
\text { tail and a hydrophilic tail. } \\
\text { - Hydrophilic tail causes } \\
\text { surfactant to dissolve in water } \\
\text { which increases solubility of } \\
\text { PCHs. } \\
\text { - Hydrophobic tail gathers at } \\
\text { interface, reducing the surface } \\
\text { tension which increases the } \\
\text { mobility of PCHs. }\end{array}$ & {$[3,19]$} \\
\hline 4. & Freezer/Thaw & $\begin{array}{l}\text { - This method is basically } \\
\text { adapting demulsification } \\
\text { process where the water is } \\
\text { removed from W/O emulsion } \\
\text { into two phases. } \\
\text { - Divided into two mechanism. } \\
\text { - First mechanism, water freezers } \\
\text { first and then followed by oil. } \\
\text { - Second mechanism, oil freezers } \\
\text { first then followed by water. }\end{array}$ & {$[3,20]$} \\
\hline 5. & Pyrolysis & $\begin{array}{l}\text { - High capital, maintenance, and } \\
\text { operating cost, high } \\
\text { consumption of energy, and not } \\
\text { suitable for oil sludge with high } \\
\text { moisture content. }\end{array}$ & {$[3,21]$} \\
\hline 6. & $\begin{array}{l}\text { Microwave } \\
\text { Irridiation }\end{array}$ & $\begin{array}{l}\text { - Heat is directly penetrated } \\
\text { through the molecular } \\
\text { interaction which fastens the } \\
\text { heating process. } \\
\text { - Adapts demulsification process } \\
\text { by quickly increasing the } \\
\text { temperature of emulsion. } \\
\text { - Breakdown heavy hydrocarbons } \\
\text { into lighter hydrocarbons. }\end{array}$ & {$[3,22]$} \\
\hline 7. & $\begin{array}{l}\text { Electrokinecti } \\
\text { c Method }\end{array}$ & $\begin{array}{l}\text { - Utilizes a low-intensity direct } \\
\text { current across an electrode pair } \\
\text { on each side of a porous } \\
\text { medium- electro osmosis of } \\
\text { liquid phase, migration of ions } \\
\text { and electrophoresis of charged } \\
\text { particles in a colloidal system to } \\
\text { the respective electrode. }\end{array}$ & {$[3,23]$} \\
\hline 8. & $\begin{array}{l}\text { Ultrasonic } \\
\text { Irradiation }\end{array}$ & $\begin{array}{l}\text { - Effective for removing adsorbed } \\
\text { materials from solid particles, } \\
\text { separating solid/liquid in } \\
\text { high-concentration } \\
\text { suspensions, and decreasing the } \\
\text { stability of W/O emulsion. }\end{array}$ & {$[3,20]$} \\
\hline 9. & Froth Notation & $\begin{array}{l}\text { - Purpose is too separate water } \\
\text { from the sludge. } \\
\text { - To shape sleek oil slurry water is } \\
\text { blended with slick slop. } \\
\text { - When air reacts with the slurry, } \\
\text { air bubbles approach the oil } \\
\text { beads. } \\
\text { - This process can quickly rise to } \\
\text { the highest point of water-oil } \\
\text { blend, and the cumulative oil } \\
\text { can be skimmed off and } \\
\text { gathered for promote }\end{array}$ & {$[3,24]$} \\
\hline
\end{tabular}

gathered for promote and Engin IJTRE 


\begin{tabular}{|l|l|l|l|}
\hline 10. & Composting & $\begin{array}{l}\text { - Involves the application of } \\
\text { microorganism. } \\
\text { Banish the organic } \\
\text { contamination with the } \\
\text { presence of oxygen. }\end{array}$ & \\
- Fastens the deprivation of PHC \\
utilizing microorganism. \\
- These processes might happen \\
naturally or unnaturally \\
industrialized in the research \\
centers. \\
The result for the reaction is \\
either it gobbles up the \\
impurities or captivate them \\
inside (example, encompassing \\
substantial metals)
\end{tabular}

Based on the table above, compared to the studies for the conventional sludge treatment process such as, freeze/thaw, pyrolysis and microwave irradiation consumes a huge amount of energy which leads to increase in disposal cost.

However, this study has chosen a method of composting to treat the petroleum sludge as composting is one of the economical methods to be operated. Moreover, composting is the most environmentally friendly treatment method.

\section{Co-composting}

Composting process is known as one of the productive methods to deal with petroleum sludge [6]. It offers a low cost to perform the process $[6,14]$ and, uncomplicated plan and activity [14]. Composting is a process of decomposing organic matter with the presence of oxygen into a safe final product, uncontaminated by phytotoxicity and pathogens, and humus-like material $[25,26]$. The microorganisms petrified and digested the simple organic carbon compounds resulting the production of carbon, nitrogen, water, organic acids and heat [25]. The compost produced by the composting process is the enhancement of the soil in term of physical, chemical, and microbiological properties [26].

The process of composting can be used for different types of wastes such as on animal manures [25], food wastes [27], kitchen and garden wastes [28], sewage sludge [29], household organic waste [30] etc. However, studies shown some different methods of composting previously. The methods are vermicomposting, on-site composting, aerated (turned) windrow composting, aerated static composting, in-vessel composting etc.

There are several factors that influence the composting process such as temperature, $\mathrm{pH}$ value, moisture level, oxygen level, and carbon to nitrogen nutrient ratio.

1) $\mathrm{pH}$ Value

pH level effects the degradation process of bacteria and fungi performance. Hence, optimum $\mathrm{pH}$ value is needed to enhance the biodegradation process. 7 to 7.8 is the optimum $\mathrm{pH}$ value [6].

2) Moisture Level

Enzymatic activity required moisture to operated. The moisture presence in the treatment matrix enhanced the availability of target molecules to the microorganisms. Optimal water content is between 10 to $20 \%$ by mass. While the optimum activity occurs when the moisture reaches 50 to $80 \%$ [6].

3) Oxygen Level
Oxygen is needed for oil sludge components to breakdown. The presence of oxygen leads to the great efficiency of natural microbial hydrocarbon degradation [6].

4) Carbon to Nitrogen Ratio

Oxygen is needed for oil sludge components to breakdown. The presence of oxygen leads to the great efficiency of natural microbial hydrocarbon degradation [6].

5) Temperature

High temperature in the sludge compost enhance the dissolvability of contaminants and initiated higher metabolic action of the compost. The increasing in temperature also caused by the microbial activities. Therefore, low temperature decreased the rate of degradation and affect the microbial growth [6].

\section{E. Bulking Agent for Composting}

Bulking agent aid to control the air supply, moisture and other important composting parameters. Sawdust provides high carbon to nitrogen content in composting. It also has the capability to control the moisture and gives better aeration during the composting process. In this study, sawdust as a bulking agent and poultry manure are used. Table V shows the selected properties of sawdust used in previous study.

Table- V: Selected properties of Bulking Agent

\begin{tabular}{|l|r|r|}
\hline \multicolumn{1}{|c|}{ Parameter } & \multicolumn{1}{c|}{ Sawdust } & Ref \\
\hline $\mathrm{pH}$ & $7.30 \pm 0.20$ & \\
\cline { 1 - 2 } Moisture (\%) & $32.0 \pm 3.8$ & \multirow{2}{*}{ [13] } \\
\cline { 1 - 2 } TOC $(\%)$ & $53.25 \pm 1.57$ & \\
\cline { 1 - 2 } Total N (\%) & $0.130 \pm 0.0400$ & \\
\hline C:N ratio & $410: 1$ & \\
\hline
\end{tabular}

\section{F. Properties of Poultry Manure}

Poultry manure is nitrogen-rich materials and is of economic importance as organic fertilizers, feed supplements or as energy sources [31]. Poultry manure commitment to soil richness as for supplement accessibility and microbial load addition has likewise been explored [32]. Table VI shows nutrient content of different types of poultry manure from previous study.

Table- VI: Nutrient Content of different types of Poultry Manure

\begin{tabular}{|l|l|l|l|l|}
\hline \multicolumn{1}{|c|}{ Nutrients } & \multicolumn{1}{|c|}{$\begin{array}{c}\text { Deep } \\
\text { Litter. }\end{array}$} & $\begin{array}{c}\text { Broiler } \\
\text { House }\end{array}$ & $\begin{array}{c}\text { Cage } \\
\text { Manure }\end{array}$ & Ref \\
\hline C:N ratio & $9.5-11.5$ & $9.4-11.2$ & $5.8-7.6$ & \\
\cline { 1 - 4 } Total N (\%) & $1.7-2.2$ & $2.4-3.6$ & $3.63-5.30$ & \multirow{2}{*}{33} \\
\cline { 1 - 4 } $\begin{array}{l}\text { Total } \\
\text { Diphosphorus } \\
\text { Dioxide (\%) }\end{array}$ & $1.41-1.81$ & $1.56-2.80$ & $1.54-2.90$ \\
\cline { 1 - 4 } $\begin{array}{l}\text { Total Potassium } \\
\text { oxide (\%) }\end{array}$ & $0.93-1.30$ & $1.40-2.31$ & $2.5-2.9$ & \\
\cline { 1 - 4 } Fe (ppm) & $930-1380$ & $970-1370$ & $970-1450$ & \\
\hline
\end{tabular}




\begin{tabular}{|l|l|l|l|}
\hline $\mathrm{Zn}(\mathrm{ppm})$ & $90-380$ & $160-315$ & $290-460$ \\
\cline { 1 - 3 } $\mathrm{Cu}(\mathrm{ppm})$ & $24-42$ & $27-47$ & $80-172$ \\
\cline { 1 - 2 }$(\mathrm{ppm})$ & $210-380$ & $190-350$ & $370-590$ \\
\cline { 1 - 3 } $\mathrm{Ca}(\%)$ & $0.9-1.1$ & $0.86-1.11$ & $0.80-1.02$ \\
\cline { 1 - 2 }$(\%)$ & $0.45-0.68$ & $0.42-0.65$ & $0.40-0.56$ \\
\hline
\end{tabular}

Furthermore, study shows that the average counts of total aerobic heterotrophic bacteria (THB) and the average counts of petroleum-utilizing bacteria (PUB) in poultry manure was 138.75 x e5 (c.g.u)/g and 17.25 x e5 (c.f.u)/g, respectively [40]. Table VI demonstrate the heterotrophic bacteria (THB) isolates and petroleum-utilizing bacteria (PUB) isolates that presence in poultry manure.

Table- VII: List of Bacteria Isolates for THB \& PUB

\begin{tabular}{|l|l|l|c|}
\hline Nutrient & \multicolumn{1}{|c|}{ THB isolates } & \multicolumn{1}{|c|}{ PUB isolates } & Ref \\
\hline Poultry & Acinetobacter sp & Acinetobacter sp & \\
Manure & Bacillius sp & Micrococcus sp & \\
& Flavobacterium sp & Psedomonas sp & \\
& Klebsiella ap & & [31] \\
& Micrococcus sp & & \\
& Nocardia sp & & \\
& Psedomonas sp & & \\
& Serratia sp & & \\
\end{tabular}

\section{MATERIALS AND METHOD}

\section{A. Materials}

The petroleum sludge used in this study was from a crude oil desalter tank located in Terengganu. Figure 2 shows the petroleum sludge sample. The poultry manure used for this study is obtained from D.B.E Poultry Sdn. Bhd. The sawdust was obtained from Ipoh, Perak, which is used in this study to provide optimum free air space and regulates the water contents for the compost mix, and gardening soil was used to reduce moisture for composting due to the slurry state in petroleum sludge.

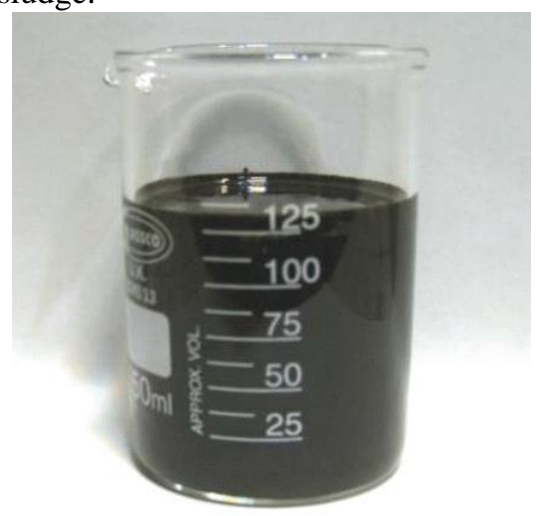

Fig. 2. Petroleum Sludge (PS) Sample

\section{B. Characterization of Petroleum Sludge}

Before characterizing the petroleum sludge, the sludge needs to go through oil recovery test by using solvent extraction method. The purpose of this test is to separate the trapped oil and sludge for further tests.

$20 \mathrm{~g}$ (wet weight) of petroleum sludge was centrifuged at room temperature with Dichloromethane as solvent in ratio of
1:1. The mixture was then agitated using a mechanical shaker at $130 \mathrm{rev} / \mathrm{min}$ for 15 minutes. The centrifugation process was performed at $5000 \mathrm{rev} / \mathrm{min}$ for 30 minutes. Following centrifugation, the tubes was removed and the supernatants (oil and solvent) will be separated and stored in a glass bottle. To concentrate the reclaimed oil, it was evaporated using a rotary evaporator. The samples then will be analyzed using Gas Chromatography/ Mass Spectrophotometry (GC/MS) and Atomic Absorption Spectrometer (AAS) for PAH and heavy metals content.

\section{C. pH Analysis}

$5 \mathrm{~g}$ of sample was added with distilled water. The sample was mixed and allowed to stand for 10 minutes before measuring $\mathrm{pH}$ by using $\mathrm{pH}$ meter (YSI ProDSS multi-parameter Water Quality Meter).

\section{Total Organic Carbon (TOC) Analysis}

TOC test was done to determine the carbon content in the petroleum sludge, sawdust, poultry manure and soil. Thus, it can be compared with the nitrogen content obtained from TKN test to get the carbon to nitrogen ratio for further analysis.

\section{E. Total Kjeldahl Nitrogen (TKN) Analysis}

$15 \mathrm{~mL}$ of sample was measured in a graduated cylinder and transferred to the digestion flask. 10 selenium tablets was added as catalyst into the sample. Then, $20 \mathrm{~mL}$ of sulfuric acid was added into each sample. The flasks were placed into a digestion unit K-435 for 60 minutes in an acid fume hood. After 60 minutes, the flasks are removed and let cool for about 45 minutes to 1 hour in the fume hood, then is diluted with 50 $\mathrm{mL}$ of distilled water before being transferred to the distillation unit. During digestion, the nitrogen bonds in the sample was broken and the organically bonded nitrogen was converted into ammonium ions. One flask per time is placed in a distillation unit for distillation and titration process. 70 $\mathrm{mL}$ of sodium hydroxide was added to the vial followed by 60 $\mathrm{mL}$ of boric acid. The $\mathrm{pH}$ was measured automatically by distillation unit. During distillation, the ammonium ions were converted into ammonia by adding sodium hydroxide. The ammonia was then transferred into the steam distillation. The steam distillation was filled with an absorbing solution in order to capture the dissolved ammonia gas. $20 \mathrm{~mL}$ of $0.25 \mathrm{M}$ sulfuric acid was used as an absorbing solution, the residual sulfuric acid is titrated with sodium hydroxide standard solution. The solution was titrated until it reaches $\mathrm{pH}$ value of 4.65. The volume of sulfuric acid was recorded.

\section{F. Co-composting}

This treatment was done to find the optimum ratio for petroleum sludge, sawdust, soil and poultry manure by observing the activity of the composting process. Petroleum sludge was mixed with sawdust, soil and poultry manure in different ratios of 1:1:1:0 (control), 1:1:1:5, 1:1:1:8 and $1: 1: 1: 10$. Each ratio was prepared in triplicates as shown in Figure 3. Required quantity of each mixture was taken for analyses at the beginning of the composting process. The samples was observed for period of 2 weeks. Two weeks period was chosen is because

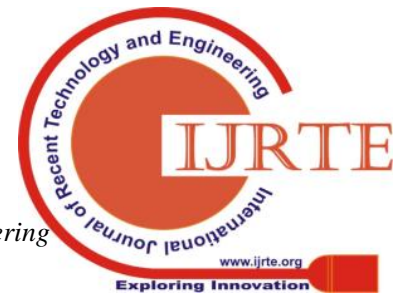


the bacteria present in the poultry manure are mostly have shorter lag and log period such as Pseudomonas spp. After two weeks the bacteria started to enter stationery and death phase which will reduce the degradation rate [34]. Samples was turned daily for optimum process. The mixtures are sprayed by using tap water to maintain the moisture content. Temperature was recorded by inserting the thermometer in the center of the composting mix before turning. Required quantity of each mixture was taken after the composting process for further analyses.

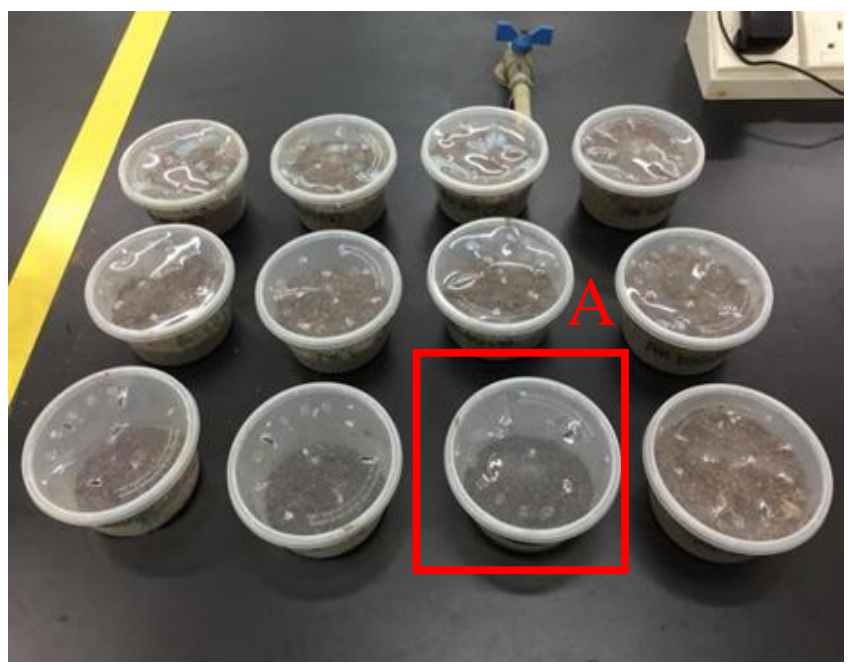

Fig. 3. (a) Experimental set-up for composting in different ratios

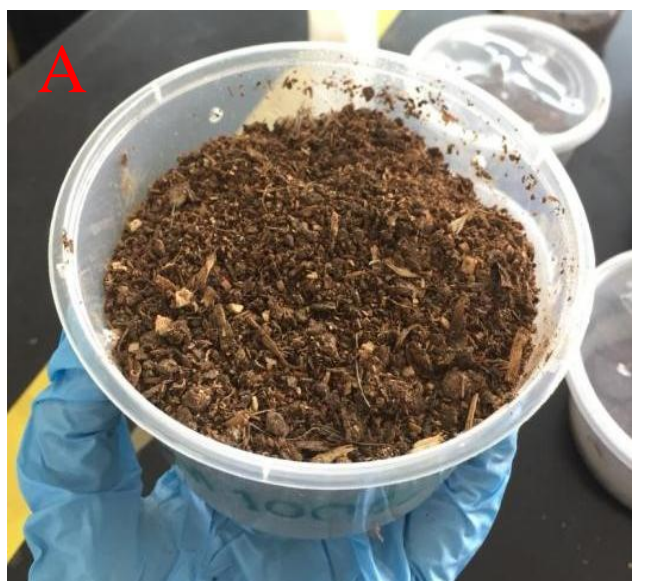

Fig. 3.(b) Sample of composting ratio mix

\section{RESULTS AND DISCUSSION}

\section{A. Introduction}

Various of tests and experiments have been carried out in this study. The value obtained from petroleum sludge such as PAHs, heavy metals and TOG content are expected to be reduced after being composted. The carbon and nitrogen value are known after doing TOC and TKN tests, thus gave the optimum ratio of the compost mix. Besides, the moisture content of the compost mix in preliminaries treatment is maintained to optimum the process of composting.

\section{B. General Properties of Materials}

From the tests carried out, shown the general properties of the raw materials for composting in Table VIII.

Table- VIII: General properties of Raw Materials

\begin{tabular}{|l|l|l|c|c|c|}
\hline Parameter & Unit & \multicolumn{1}{|c|}{ PS } & $\begin{array}{c}\text { Sawdus } \\
\mathbf{t}\end{array}$ & \multicolumn{1}{|c|}{ Soil } & $\begin{array}{c}\text { Poultry } \\
\text { Manur } \\
\mathbf{e}\end{array}$ \\
\hline TOG & $\mathrm{mg} / 1$ & 65.1 & - & - & - \\
\hline TKN & $\mathrm{mg} / 1$ & 317.56 & 320.09 & 115.67 & 13564 \\
\hline TOC & $\%$ & 99.7 & 33.56 & 1.24 & 56.13 \\
\hline $\begin{array}{l}\text { Moisture } \\
\text { Content }\end{array}$ & $\%$ & 60 & 14 & 29 & 18 \\
\hline $\mathrm{pH}$ & - & 6.92 & 7.99 & 4.73 & 8.34 \\
\hline
\end{tabular}

From the table above, poultry manure has the highest TKN concentration. Therefore, poultry manure provides the nitrogen source to the compost mix to maintain the $\mathrm{C}: \mathrm{N}$ ratio besides, providing the bacteria source. In addition, sawdust also provides nitrogen to the compost mix. The results demonstrate that PS contains the highest TOC (99.7\%) since, PS is mostly containing hydrocarbons. The high carbon source will provide nutrient for the bacteria in the composting process. Furthermore, PS also contains the highest moisture content at $60 \%$ compare to other raw materials. As stated, by previous studies, PS is classified as a complex and stable water-oil emulsion-suspension system which cause the moisture content to be high. In contrary, sawdust contains lowest moisture content among the raw materials. Therefore, sawdust also acts as a moisture reducing agent in the compost mix other than providing the carbon \& nitrogen source in the compost mx. The $\mathrm{pH}$ value of all the materials is slightly alkaline. this alkalinity characteristics are suitable for composting. Therefore, further $\mathrm{pH}$ value adjustment is not vital in the compost mix.

\section{Polycyclic Aromatic Hydrocarbon (PAH) \& Heavy Metals Content in Petroleum Sludge.}

The Gas Chromatography/ Mass Spectrophotometry (GC/MS) machine is used to characterize the petroleum sludge. The result for PAHs available in petroleum sludge is shown in Table IX below.

Table- IX: Concentration of PAH in PS

\begin{tabular}{|c|c|c|}
\hline No & Compound & $\begin{array}{c}\begin{array}{c}\text { Concentration } \\
(\mathbf{p p b})\end{array} \\
\end{array}$ \\
\hline 1. & Benzo (b) fluoranthene & 1.34 \\
\hline 2. & Chrysene & 0.98 \\
\hline 3. & Benzo (a) anthracene & 0.77 \\
\hline 4. & Carbazole & 0.76 \\
\hline 5. & Pyrene & 0.28 \\
\hline 6. & Anthracene & 0.10 \\
\hline 7. & Benzo $(\mathrm{g}, \mathrm{h}, \mathrm{i})$ perylene & 0.09 \\
\hline 8. & Fluoranthene & 0.08 \\
\hline 9. & Acenaphthylene & 0.05 \\
\hline 10 & Acenaphthene & 0.04 \\
\hline
\end{tabular}




\begin{tabular}{|l|l|l|}
\hline $\begin{array}{l}11 \\
.\end{array}$ & Benzo (a) pyrene & 0.03 \\
\hline $\begin{array}{l}12 \\
.\end{array}$ & Benzo (k) fluoranthene & 0.01 \\
\hline $\begin{array}{l}13 \\
.\end{array}$ & Indeno (1,2,3-cd) pyrene & 0.01 \\
\hline $\begin{array}{l}14 \\
.\end{array}$ & Dibenzo (a,h) anthracene & 0.01 \\
\hline
\end{tabular}

Result shows there are fourteen (14) PAHs compound detected in the petroleum sludge. Benzo (b) fluoranthene contains the highest concentration and Dibenzo $(\mathrm{a}, \mathrm{b})$ antharacene contains the least concentration in PS. All hydrocarbon compounds presented above consist of 1-6 aromatic rings.

Besides detecting the PAHs in the petroleum sludge, a test to find the available heavy metals is also being carried out. Atomic Absorption Spectrometer (AAS) machine is used to find the heavy metals content in the petroleum sludge. Figure 4 shows the heavy metals concentration present in PS.

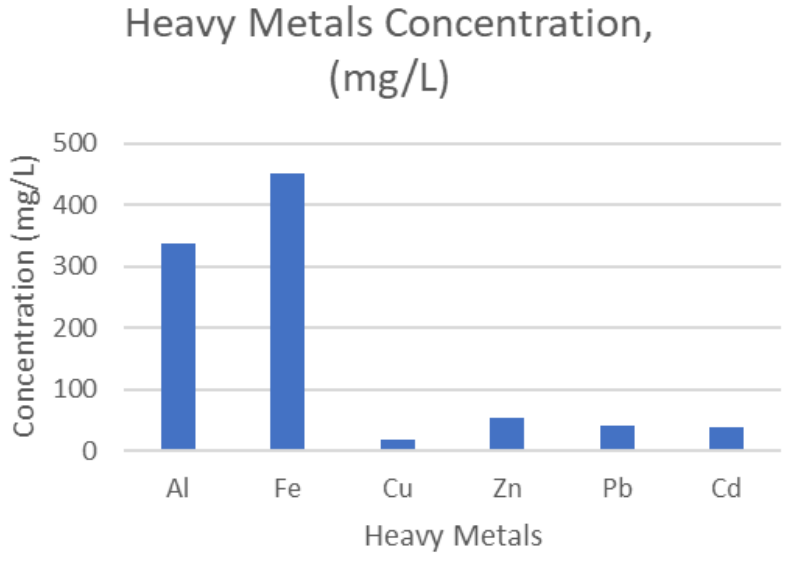

Fig. 4. Heavy Metals Concentration in PS

Based on the figure above, $\mathrm{Fe}>\mathrm{Al}>\mathrm{Zn}>\mathrm{Pb}>\mathrm{Cd}>\mathrm{Cu}$. $\mathrm{Fe}$ occurs as most concentration heavy metal present in petroleum sludge while $\mathrm{Cu}$ occurs as the least concentration heavy metal present in petroleum sludge.

D. Comparison of Polycyclic Aromatic Hydrocarbon (PAH) Before \& After Composting

Result in Table X shows the compost mix in ratio of 1:1:1:8 with a reduction rate of $3.43 \%$ has the most total reduction in PAHs compared to other ratios. Based on the value reduction in each compound found that composting is very effective in reducing 1-4 ring PAH but not effective in reducing 5-6 ring PAH. This also proves that composting can be promising treatment method that can be used to treat the petroleum sludge.

Table- X: PAH Concentration in Compost Mix after composting.

\begin{tabular}{|c|c|c|c|c|c|c|}
\hline \multirow[t]{2}{*}{ No. } & \multirow[t]{2}{*}{ Compound } & \multirow{2}{*}{$\begin{array}{c}\text { Concentration } \\
\text { (ppb) }\end{array}$} & \multicolumn{4}{|c|}{ Concentration in compost mix after composting } \\
\hline & & & $\begin{array}{c}\text { Compost mix ratio } \\
1: 1: 1: 0\end{array}$ & $\begin{array}{c}\text { Compost mix ratio } \\
1: 1: 1: 5\end{array}$ & $\begin{array}{c}\text { Compost mix ratio } \\
\text { 1:1:1:8 }\end{array}$ & $\begin{array}{c}\text { Compost mix } \\
\text { ratio } \\
1: 1: 1: 10\end{array}$ \\
\hline 1 & Benzo (b) fluoranthene & 1.34 & 1.339 & 1.337 & 1.335 & 1.335 \\
\hline 2 & Chrysene & 0.98 & 0.979 & 0.967 & 0.967 & 0.969 \\
\hline 3 & Benzo (a) anthracene & 0.77 & 0.770 & 0.768 & 0.766 & 0.769 \\
\hline 4 & Carbazole & 0.76 & 0.756 & 0.756 & 0.743 & 0.749 \\
\hline 5 & Pyrene & 0.28 & 0.279 & 0.267 & 0.265 & 0.268 \\
\hline 6 & Anthracene & 0.10 & 0.08 & 0.07 & 0.07 & 0.08 \\
\hline 7 & Benzo $(\mathrm{g}, \mathrm{h}, \mathrm{i})$ perylene & 0.09 & 0.087 & 0.086 & 0.075 & 0.082 \\
\hline 8 & Fluoranthene & 0.08 & 0.075 & 0.071 & 0.069 & 0.073 \\
\hline 9 & Acenaphthylene & 0.05 & 0.047 & 0.032 & 0.028 & 0.030 \\
\hline 10 & Acenapthene & 0.04 & 0.038 & 0.031 & 0.027 & 0.029 \\
\hline 11 & Benzo (a) pyrene & 0.03 & 0.027 & 0.026 & 0.023 & 0.024 \\
\hline 12 & Benzo (k) fluoranthene & 0.01 & 0.01 & 0.01 & 0.009 & 0.009 \\
\hline 13 & Indeno $(1,2,3-c, d)$ pyrene & 0.01 & 0.01 & 0.01 & 0.009 & 0.009 \\
\hline 14 & Dibenzo )a,h) anthracene & 0.01 & 0.009 & 0.008 & 0.008 & 0.009 \\
\hline \multicolumn{2}{|c|}{ Total PAH Concentration (ppb) } & 4.55 & 4.506 & 4.439 & 4.394 & 4.435 \\
\hline \multicolumn{3}{|c|}{ Total PAH Reduction (\%) } & 0.97 & 2.44 & 3.43 & 2.53 \\
\hline
\end{tabular}

E. Comparison of heavy metals before \& after composting.
Table- XI: Comparison of Heavy Metals 


\begin{tabular}{|l|l|c|c|c|c|c|c|}
\hline No. & Element & $\begin{array}{c}\text { Concentration } \\
(\mathbf{m g} / \mathbf{l})\end{array}$ & \multicolumn{3}{|c|}{$\begin{array}{c}\text { Concentration after composting } \\
\text { (mg/l) }\end{array}$} & $\begin{array}{c}\text { Reduction } \\
\text { in 1:1:1:10 }\end{array}$ \\
\cline { 4 - 7 } & & & $\mathbf{1 : 1 : 1 : 0}$ & $\mathbf{1 : 1 : 1 : 5}$ & $\mathbf{1 : 1 : 1 : 8}$ & $\mathbf{1 : 1 : 1 : 1 0}$ & $\mathbf{( \% )}$ \\
\hline $\mathbf{1}$ & $\mathrm{Al}$ & 338.07 & 340.74 & 337.64 & 329.89 & 327.75 & 3.05 \\
\hline $\mathbf{2}$ & $\mathrm{Fe}$ & 450.65 & 453.08 & 459.23 & 437.02 & 438.96 & 2.67 \\
\hline $\mathbf{3}$ & $\mathrm{Cu}$ & 19.56 & 19.75 & 19.38 & 19.04 & 18.90 & 3.37 \\
\hline $\mathbf{4}$ & $\mathrm{Zn}$ & 52.70 & 53.07 & 54.67 & 52.86 & 52.64 & 0.11 \\
\hline $\mathbf{5}$ & $\mathrm{Pb}$ & 40.73 & 41.05 & 40.88 & 38.97 & 37.00 & 9.16 \\
\hline $\mathbf{6}$ & $\mathrm{Cd}$ & 39.56 & 40.94 & 40.61 & 38.76 & 37.01 & 6.45 \\
\hline
\end{tabular}

Table above shows the highest heavy metals reduction occurs in ratio $1: 1: 1: 10$. Based on the result, the volume of the poultry manure effected the total heavy metals reduction. However, in both ratios of $1: 1: 1: 0$ and $1: 1: 1: 5$ occur to be slightly higher than petroleum sludge itself. The poultry manure and sawdust itself content heavy metals which resulted in the increasing of heavy metals value in ratios of $1: 1: 1: 0$ and $1: 1: 1: 5$.

\section{F. Total Kjeldahl Nitrogen (TKN) in Compost Mix During Composting Process}

Four (4) different ratios of compost mix (1:1:1:0, 1:1:1:5, $1: 1: 1: 8$ and $1: 1: 1: 10$ ) are tested to determine the nitrogen value. The ratios are generally consisted of petroleum sludge, sawdust, soil and poultry manure.

\section{Total Kjedahl Nitrogen vs Period of Time}

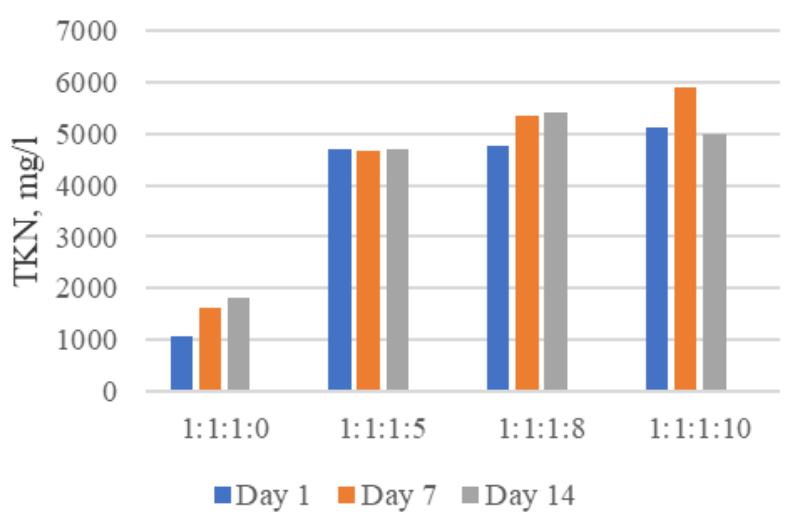

Fig. 5. TKN Content in Compost Mix

Result shows the more volume of poultry manure is added, the more nitrogen value is obtained. Compost mix which is in ratio 1:1:1:0 also acted as a control is the lowest among others because of the absent of poultry manure. While in second ratio $(1: 1: 1: 5)$ is increased by only $0.06 \%$ because the microbes are in adaptation phase where it starts to produce ammonia when the poultry manure is added.

The third ratio $(1: 1: 1: 8)$ increased by $13.49 \%$ which is higher than the second ratio because of more poultry manure added. The microbes are already adapted with the ratio present in the compost mix. The 1:1:1:10 ratio occurs to reduce by $2.57 \%$ because of more poultry manure added. The microbes are already reached the optimum ratio of poultry manure hence the nitrogen value decreased.

\section{G. Total Organic Carbon (TOC) in Compost During Composting Process}

Graph below shows the total organic carbon in each ratio
$(1: 1: 1: 0,1: 1: 1: 5,1: 1: 1: 8$ and $1: 1: 1: 10)$ on 1 st, 7 th, and 14 th day.

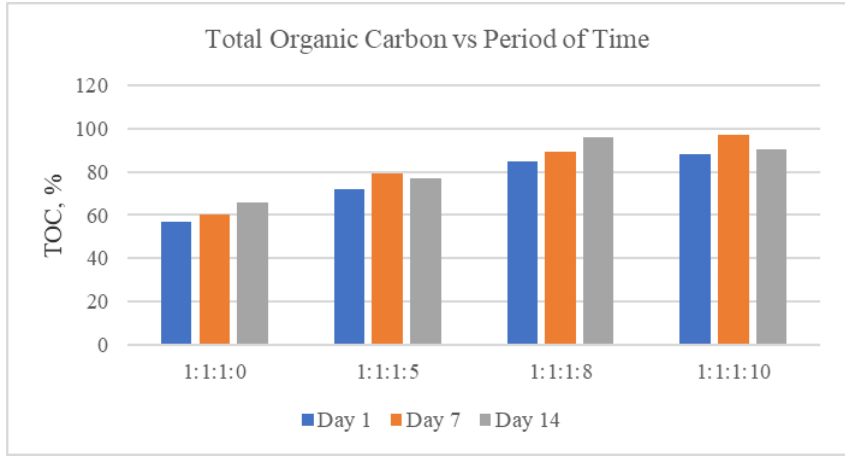

Fig. 6. TOC Content in Compost Mix

Result shows the control ratio $(1: 1: 1: 0)$ is increased by $15.96 \%$ of carbon because of no poultry manure is added. The second ratio only increased by $6.91 \%$ where the microbes are in adaptation phase with the presence of poultry manure. They start to use the carbon source as their food. Besides, in the third ratio, when more poultry manure is added, the higher the TOC obtained.

Further, when more poultry manure is added (1:1:1:10) the microbes cannot adapt with the ratio anymore hence the reduction in TOC observed.

\section{H. Carban to Nitrogen (C:N) Ratio in Compost Mix During Composting Process}

Carbon to Nitrogen $(\mathrm{C}: \mathrm{N})$ ratio is one of the important factor that need to be maintained throughout the composting process because $\mathrm{C}: \mathrm{N}$ ratio provides nutrients to the sludge compost. It provides nutrient for the microorganisms to undergo cell metabolism. The $\mathrm{C}: \mathrm{N}$ ratio was sustained at a range of 25 to 30 throughout the composting process. If the carbon content is higher than nitrogen content in the compost mix, it will increase the duration of composting. The increase in carbon will cause the bacteria adaption time to increase which lead to increase in composting duration. On the contrary, if the carbon content is lower than nitrogen content, it will cause the bacteria to be inactive due to lack of nutrient [6].

\section{CONCLUSION}

Best performing ratio of petroleum sludge, sawdust, soil and poultry manure for composting has been confirmed for the third ratio which is $1: 1: 1: 8$. Even though the fourth ratio $(1: 1: 1: 10)$ has the highest total reduction in heavy metals, however the nutrient value is higher in third (1:1:1:8). Therefore, it can be concluded that compost mix design $1: 1: 1: 8$ is the optimum ratio for effective and efficient degradation of PS.

Furthermore, the efficiency level of composting is much higher compare to the current practice in accordance with the sustainability and environment aspect. The current industry practice in treating PS is incineration and landfilling. But this method has major drawbacks in accordance with sustainability environment. Therefore, composting is suitable to treat 
the petroleum sludge because of its economic and environmental impact. Composting also adapts zero waste principle whereabout it converts waste into useful materials which can be explained by this phrase "Waste to Wealth".

Composting should be applied more in real life not only in papers to reduce the waste volume produced by the petroleum industries. Petroleum industries should give more concerns regarding the treatment of petroleum waste products to prevent the unwanted events from happening such as environmental pollution and risk to human health.

\section{ACKNOWLEDGEMENT}

The authors would like to thank Universiti Teknologi PETRONAS for financial and technical support. The study has been supported by the university grant (URIF-015LB0-030).

\section{REFERENCES}

1. Huang, Q., et al., Characterization of emulsified water in petroleum sludge. 2014. 118: p. 214-219.

2. Vdovenko, S., S. Boichenko, and V. Kochubei, Composition and properties of petroleum sludge produced at the refineries. 2015.

3. $\mathrm{Hu}, \mathrm{G} ., \mathrm{J} . \mathrm{Li}$, and G.J.J.o.h.m. Zeng, Recent development in the treatment of oily sludge from petroleum industry: a review. 2013. 261: p. 470-490.

4. Lodungi, J., et al., A Review in Oil Exploration and Production Waste Discharges According to Legislative and Waste Management Practices Perspective in Malaysia. Int J Waste Resour, 2016. 7(260): p. 2.

5. Islam, B.J.I.J.C.S., Petroleum sludge, its treatment and disposal: A review. 2015. 13(4): p. 1584-1602.

6. Prakash, V., et al., Treatment of oil sludge contamination by composting. 2015. 6(3): p. 1.

7. Atagana, H.I.J.S. and S.C.A.I. Journal, Biological degradation of crude oil refinery sludge with commercial surfactant and sewage sludge by co-composting. 2015. 24(5): p. 494-513.

8. Marín, J.A., et al., Bioremediation by composting of heavy oil refinery sludge in semiarid conditions. Biodegradation, 2006. 17(3): p. 251-261.

9. Annweiler, E., et al., Naphthalene degradation and incorporation of naphthalene-derived carbon into biomass by the thermophile Bacillus thermoleovorans. Appl Environ Microbiol, 2000. 66(2): p. 518-23.

10. Kanaly, R.A. and S. Harayama, Biodegradation of high-molecular-weight polycyclic aromatic hydrocarbons by bacteria. J Bacteriol, 2000. 182(8): p. 2059-67.

11. Meyer, S., H.J.W. Steinhart, Air,, and S. Pollution, Fate of PAHs and hetero-PAHs during biodegradation in a model soil/compost-system: formation of extractable metabolites. 2001. 132(3-4): p. 215-231.

12. Iglesias-Groth, S., et al., A search for interstellar anthracene towards the Perseus anomalous microwave emission region. 2010. 407(4): $\mathrm{p}$. 2157-2165.

13. Ayotamuno, J.M., et al., Composting and phytoremediation treatment of petroleum sludge. 2010. 19(6): p. 686-695.

14. Koolivand, A., et al., Degradation of petroleum hydrocarbons from bottom sludge of crude oil storage tanks using in-vessel composting followed by oxidation with hydrogen peroxide and Fenton. 2013. 15(3): p. 321-327.

15. Alhadj-Mallah, M.-M., et al., The leaching behavior of toxic metals in petroleum sludge after thermal treatment. Petroleum Science and Technology, 2015. 33(1): p. 118-126.

16. Asgari, A., et al., Biodegradation of total petroleum hydrocarbons from acidic sludge produced by re-refinery industries of waste oil using in-vessel composting. 2017. 15(1): p. 3.

17. El Naggar, A., et al., Petroleum cuts as solvent extractor for oil recovery from petroleum sludge. 2010. 1(1): p. 10-19.

18. da Silva, L.J., et al., A review of the technological solutions for the treatment of oily sludges from petroleum refineries. 2012. 30(10): p. 1016-1030

19. Yan, P., et al., Oil recovery from refinery oily sludge using a rhamnolipid biosurfactant-producing Pseudomonas. Bioresource Technology, 2012. 116: p. 24-28.
20. Zhang, J., et al., Oil recovery from refinery oily sludge via ultrasound and freeze/thaw. Journal of Hazardous Materials, 2012. 203-204: p. 195-203.

21. Liu, J., et al., Pyrolysis treatment of oil sludge and model-free kinetics analysis. Journal of Hazardous Materials, 2009. 161(2): p. 1208-1215.

22. Abdulbari, H.A., et al., Demulsification of petroleum emulsions using microwave separation method. 2011. 6(23): p. 5376-5382

23. Elektorowicz, M., S. Habibi, and R. Chifrina, Effect of electrical potential on the electro-demulsification of oily sludge. Journal of Colloid and Interface Science, 2006. 295(2): p. 535-541.

24. Stasiuk, E.N. and L.L. Schramm, The influence of solvent and demulsifier additions on nascent froth formation during flotation recovery of Bitumen from Athabasca oil sands. Fuel Processing Technology, 2001. 73(2): p. 95-110.

25. Bernal, M.P., J. Alburquerque, and R. Moral, Composting of animal manures and chemical criteria for compost maturity assessment. A review. Bioresource technology, 2009. 100(22): p. 5444-5453.

26. Sánchez, Ó.J., D.A. Ospina, and S. Montoya, Compost supplementation with nutrients and microorganisms in composting process. Waste management, 2017. 69: p. 136-153.

27. Cerda, A., et al., Composting of food wastes: status and challenges. Bioresource technology, 2018. 248: p. 57-67.

28. Arrigoni, J.P., et al., Inside the small-scale composting of kitchen and garden wastes: Thermal performance and stratification effect in vertical compost bins. Waste Management, 2018. 76: p. 284-293.

29. Nafez, A.H., et al., Sewage sludge composting: quality assessment for agricultural application. Environmental monitoring and assessment, 2015. 187(11): p. 709.

30. Karnchanawong, S. and N. Suriyanon, Household organic waste composting using bins with different types of passive aeration. Resources, Conservation and Recycling, 2011. 55(5): p. 548-553.

31. Akinde, S. and O. Obire, Aerobic heterotrophic bacteria and petroleum-utilizing bacteria from cow dung and poultry manure. World Journal of Microbiology and Biotechnology, 2008. 24(9): p. 1999-2002.

32. Obire, O. and S. Akinde, Poultry manure amendment of oil polluted soils for sustainable development in the Niger-Delta. J. Niger Environ. Soc, 2004. 2: p. 138-143.

33. Amanullah, M.M., et al., Nutrient uptake, tuber yield of cassava (Manihot esculenta Crantz.) and soil fertility as influenced by organic manures. Journal of Agronomy, 2007. 6(1): p. 183.

34. Das, N. and P. Chandran, Microbial degradation of petroleum hydrocarbon contaminants: an overview. Biotechnology research international, 2011. 2011

AUTHORS PROFILE

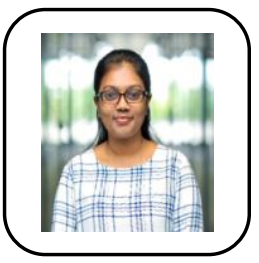

Dr. Lavania Baloo is a Senior Lecturer in Universiti Teknologi PETRONAS, Malaysia. She holds $\mathrm{PhD}$ in Civil Engineering, M.Eng in Environmental Management and Bsc in Industrial Biology. She has published few ISI papers with $\mathrm{H}$-index of 6 and participated in international conference. Secured several international grants from Indonesia, India, Philippines and national grant - YUTP. Registered member of International Water Association (IWA) and Malaysia Water Association (MWA). Won Silver medal for Malaysia International Invention, Innovation, and Technology Exhibition (ITEX) 2019. She has successfully filed two Intellectual Property under her. Has delivered few short courses for Wastewater Treatment System and Mercury in Oil and Gas Industries, in Malaysia.

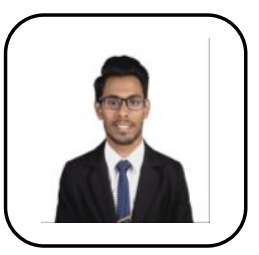

Ruvindran Vasu is a post graduate student in Universiti Teknologi PETRONAS who is currently pursing his master's degree by research. He holds Bachelor of Degree in Civil Engineering. He has participated in several international and university level exhibition. He has core specialization in Sustainable Design and Construction. Currently, he is conducting his research in Waste Management. Won Bronze medal in $5^{\text {th }}$ International Biotechnology Competition and Exhibition 2019 at Universiti Teknologi Malaysia. He also won Gold medal and Best Poster award in $42^{\text {nd }}$ Science and Engineering Design Exhibition which was organized by Universiti Teknologi PETRONAS. 
Nuraziany Binti Mohd Azmi holds Bachelor of Degree in Civil Engineering from Universiti Teknologi PETRONAS. She won Gold medal in $39^{\text {th }}$ Science and Engineering Design Exhibition which was organized by Universiti Teknologi PETRONAS. She has core specialization in Sustainable Design and Construction.

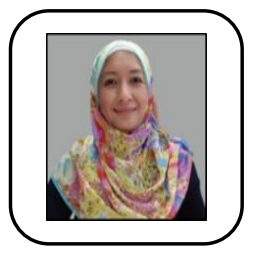

Assoc. Prof. Dr. Noor Amila Wan Abdullah Zawawi, is currently the Director of the Institute of Sustainable Building (ISB) at Universiti Teknologi PETRONAS (UTP). She is currently leading research on decommissioning of offshore platform at the Offshore Engineering Centre, UTP, and under the ISB, she is focusing on construction management and sustainability, i.e. low carbon and green building initiatives at the Center for Urban Resources (CUReS). She provides numerous training on decommissioning to the industry in Malaysia, South Korea and Netherlands, working closely with various industry/university. She works with non-profit organisations and NGOs i.e. Malaysia Structural Steel Association (MSSA) and MOGSC. Since 2015, she has been appointed as Chairperson for Rigs.volution Working Group in MSSA (a joint initiative between UTP MSSA - CIDB), and Council Member for MSSA since 2017. She is active in SPE Decommissioning events. She is listed in the National Industry Expert Directory as a Panel member for the National Occupational Skills Standard (NOSS) for Oil \& Gas, by the Department of Skills Development, Ministry of Human Resources Malaysia. Dr Amila has published over 70 articles on her research findings, and passionately championed development of local capability in decommissioning. She has been invited as speakers on decommissioning at local and international engagements since 2013. She obtained her MSc and PhD from Malaysia in Building Engineering and Built Environment. 